\title{
THE RATIONALITY OF CREATION IN FATHER DUMITRU STĂNILOAE'S THEOLOGY
}

\section{Roger-Cristian SAFTA*}

\begin{abstract}
For Father Stăniloae, Orthodox teaching on the creation of the world through the divine Logos, the Supreme Reason, highlights that the entire creation is based on a logical order, on rationality, which is the very intimate structure of creation. Thus creation does not have an autonomous structure, but a theonomous one. The rationality of the world has its grounds or foundation in the everlasting reason of the Logos, the world itself being a plasticized rationality. The world was created by the Word through the word, and the human being has been the image of the Word. What arises from this is that the world is the way or medium of the dialogue between man and the Word. Pondering and knowing the world and oneself in its rationality, the human being comes to know the Son; or, in other words, he knows himself and the world through the Son and through this man reaches the Father, since he complies with "the image" of the Image of the Father; and everything is undertaken through the Holy Spirit. Advancing in knowledge of the world rationality, of the meanings that the Word has placed in it, man uses the materiality of the world according to the world's reason, on the one hand, while, on the other hand, he enhances and enriches himself spiritually by discovering deeper meaning in human existence.
\end{abstract}

Keywords: Father Dumitru Stăniloae, Rationality, theology

According to Father Stăniloae, the Orthodox teaching on the creation of the world through the Divine Logos, the Supreme Reason, emphasizes the fact that the entire creation is based on a logical order, on rationality, which constitutes the very intimate structure of creation.

PhD, Lecturer, University of Piteşti, Faculty of Theology, Letters, History and Arts (Department of Theology), Pitești, Romania. 
"The entire existential creation, in its complexity, bears the expression of divine rationality, that is to say it finds its explanation in the rationality of the supreme Person"1. Therefore, the creation has both rational and spiritual grounds. The Holy Fathers stressed the fact that the entire creation and all things originate their reason in the divine Logos ${ }^{2}$. Thus, God has created all things as "plasticized and sensibilized shapes of His reasons", and the cosmos rationality reveals itself as a spiritual ground ingrained ever since the very creation by the Father through the Son, in the Holy Spirit:

"Actually, it is one and the same Reason, which through its infinity and transcendence is within itself and for itself unutterable and abyssal, therefore being beyond the entire creation and the separation and variety that lies and thinks within it, revealing itself and multiplying out of kindness in all the things emerging from it, each according to its right measure and revising (bringing back everything in itself)" 3 .

Through this rationality, it exists and persists and within it there are all the created things, since they have been created via and towards this rationality, and by persisting and moving, they commune with God"4. Oriented towards the divine Logos ever since the moment of its coming into existence, creation is led through its rational and spiritual structures through the energies of the Holy Spirit which are ingrained in the intimate structure of the matter, towards its sole aim and

1 Siţa IORDACHE, "Persoană şi comuniune în teologia Sfântului Vasile cel Mare", in Theologia Pontica, Revista Centrului de cercetări teologice, interculturale şi ecumenice "Sfântul Ioan Cassian", Year II (2009), no. 2-4, p. 212.

2 "In the Eastern theology all reasons come from the Logos, but they do not pass from the potency state to the active/act state through inherent powers, in an autonomous manner, but it updates itself via the Logos, according to the will of the Father, via the uncreated divine energies, shared by the Holy Spirit. Far from separating the world from itself, as Augustine was inclined to believe, the reasons behind things open the world towards God, in order to transfigure it"; Dumitru POPESCU, Teologie şi viaţă. Relevanţa teologiei ortodoxe în lumea contemporană, Convorbiri Cristinel Ioja, Alexandria, Cartea Ortodoxă, 2009, p. 51.

${ }^{3}$ Dumitru Stăniloae, Teologia Dogmatică Ortodoxă, vol. 1, Bucureşti, Institutul Biblic şi de Misiune al Bisericii Ortodoxe Române, 1996², p. 240.

${ }^{4}$ Saint Maximus the Confessor, Ambigua, II, $7 d$, rom. transl., introduction ad notes by D. Stăniloae, Bucureşti, Institutul Biblic şi de Misiune al Bisericii Ortodoxe Române, 2006, p. 80-81. 
accomplishment. Creation does not feature an autonomous structure, but a theonomous one. "The matter is not created as a mass prone to remain amorphous, or meant to be one-shaped... within the framework of the matter there are some powers which can be used in the service of God's harmoniously organizing the universe for the benefit of the human spirit"s.

Creation through the Son in the Holy Spirit also reveals a different aspect in the Trinitarian perichoretic communion, that of the vocation of all God's creatures; namely, that this communion is not only a reflection of the Trinitarian perichoresis in the created world, but also an ongoing imprint of the Trinitarian pattern of existence at all levels of creation. On the one hand, this process is possible through the overflowing of uncreated divine energies of the Holy Spirit, and, on the other hand, through the rationality and spiritual foundation of creation. In this way, the entire creation longs for communion both at its own level, through the Trinitarian-perichoretic structures laid through the Logos of the Father in the Holy Spirit, as well as in a transcendental manner, towards the Holy Trinity, the structure of the supreme communion-love.

"Assuming in a creative manner the theology of the Holy Fathers and in his turn being assimilated by the spirit of patristic writings, Father Stăniloae rehabilitates the theological value of the creation, highlighting the rationality of the world and of history, the dynamism of the human being as well as the position held by man in the transfiguration and union of the entire cosmos with God. In his work, man, the world and God are given an undiminished importance, and his vision on this connection is profoundly personal"

The whole world, including man as well, is God's creation out of nothing, in time. Therefore, we are shown, on the one hand, that the world is neither absolute, nor sufficient to itself in its existence, and, on the other hand, that the world and man are heading towards a final goal that they do not possess. This final goal that both the world and man are

${ }^{5}$ Dumitru STĂNILOAE, Sfânta Treime sau la început a fost iubirea, Bucureşti, Institutul Biblic şi de Misiune al Bisericii Ortodoxe Române, 2005, p. 62.

${ }^{6}$ Ovidiu VINTILĂ, "Ontologia persoanei şi dinamismul sfinţeniei în viaţa Bisericii, în teologia Părintelui Dumitru Stăniloae", in Altarul Reîntregirii, no. 1/2007, p. 256. 
heading towards shows their lack of accomplishment by means of the fact that their achievement is a cause beyond them. Their path towards this final aim shows their becoming, and what is changing and submitted to limitation (since they do not have the necessary accomplishment within themselves, but they merely aim at it) cannot be infinite and absolute, but it has a beginning. The world and man are the work of an infinite and absolute being, where they can find the achievement of their meaning and existence, but also of a personal being, as otherwise the achievement of the human being could not be possible; the infinite being can only be God - an everlasting and personal communion, fully accomplished through love.

If the world has been created for man, then its achievement is connected to man, who through his free consented effort in the spirit of Christ, through the Holy Spirit, can lead to reaching the aim for which it has been created.

Having been created through God's Word, or Divine Logos, it has a rational structure. "God is the supreme Reason, the source of the reasons of all things and of the reason inside us"7. The world's rationality arises from the everlasting reasons of the Logos, the world itself being a plasticized rationality ${ }^{8}$. The world and all the things it comprises are facets of divine reasons, which create a unity within divine $\operatorname{Logos}^{9}$, without the latter creating a multiplicity within God. "The world's plasticized reasons are created out of nothing; however, they are modelled and supported by the everlasting reasons of the Logos"10. Since the world was created by a Person, we are on the one hand shown its intentionality, and, on the other hand, the fact that it has a purpose. The world is not the product of randomness, it does not

${ }^{7}$ Dumitru StăNILOAE, Sensul ascezei monahale, Alba Iulia, Reîntregirea, 2005, p. 32-33

8 "God the Word is praised by the divine Scripture ca reasons not only because He is the One to provide reason, mind, and wisdom, but also because he possesses in Himself, from a previous period, everybody's reasons, in a unified manner and because $\mathrm{He}$ permeates everything" (ST. DiOnYsius ThE AREOPAGITE, "Despre numirile dumnezeieşti, VII, 4”, in SAINT DiONISIE AREOPAGITUL, Opere complete şi scoliile Sfântului Maxim Mărturisitorul, rom. transl. by D. Stăniloae, Bucureşti, Paideia, 1996, p. 164.

9 D. Stăniloae, "Dinamica creaţiei în Biserică”, in Ortodoxia, no. 3-4/1977, p. 282.

${ }^{10}$ IDEM, Teologia Dogmatică Ortodoxă, vol. 1, p. 231-232. 
appear out of mere chance, but it is connected with conscious existence; and this conscious existence reasoned before creating, and the thought turned into deed. "Only if the beginning of the world is free Word, interpersonal and omnipotent, the world is the result of a creation, or this Word has got creative powers from the very beginning and can permanently create, bringing along something really new in it, and it will turn it into a totally new one"11. Only from this perspective can the world, on the whole, have an explanation and a meaning for its existence. Any other origin-explanation empties it of content and condemns it to an existence without substance, empty, inexplicable and without consistency. For this reason, the Holy Fathers of the Church laid emphasis on the creation of the world through the Divine Logos: the world was created by the Word through the word. The world came into existence through the Logos, or the Divine Word. This indicates that the world has a rational structure, which is intimate accordance with the word of the Word through which it was called forth into existence. It is this rationality that lies at the foundation of the world and not randomness or chance. The material world is based on a spiritual structure, or it is structured according to spiritual criteria, and it summons the spirit. Therefore, there is no antagonism, no irreducible dualism between spirit and matter, but they both meet within the Divine Logos. Matter has a spiritual structure due to the fact that through the former, God's spirit makes its presence felt, it is imbued with grace from the moment of its coming into existence; matter is the means through which grace makes its presence felt in an intimate manner.

Thus, Father Stăniloae proved his allegiance to the theology of Saint Athanasius the Great who, following the word of Saint John the Evangelist "Through Him all things were made; without him nothing was made that has been made" (John 1,3) "he has converted the dualist and pantheist cosmology of the ancient world, into Christian cosmology, where the intelligible world and the sensible world make up one world only through the harmonious and rational order in creation, which has its gravitational centre in the Logos of the Father, through which

11 IDEM, "Cuvântul creator şi mântuitor şi veşnic înnoitor", in Mitropolia Olteniei, no. $1 / 1991$, p. 7. 
everything has been created"12.

This way Divine Logos shows itself as Pantokrator of the entire creation in the same way as Saint Athanasius the Great who states that the Divine Logos contains them all within itself. The world is not a simple uniform unity by itself, but it is diversity in unity and unity in diversity. And the One who achieves this is the One through whom the world was created out of nothing, the Divine Logos. With Him, the entire diversity of the world finds its unity; with Him unity bridges multiplicity.

The rationality of the world has its foundation in the creative Logos, but it is addressed to another rationality; namely, to a personal rationality. Since the world does not have its beginning in itself, its purpose cannot be located in itself. Due to the fact that the world has a rational structure, it needs to possess a conscious rationality outside itself to which it can address and to which it can use the rationality of the world. In this way, Father Stăniloae shows, the rationality of the world is meant for man and culminates in him. "In a special way, the Logos is present in man as rational subject. While all things are created, images of the reasons of the Logos. The human subject is the image of the Logos"13.

Man was given the word in order to perpetually bring something new to the creation, following the pattern set by the Creator, but on another level of existence, because man can also create, but not out of nothing; he can create from the creation of the Logos, and according to his rationality and that of the world. "Without the word as divine Person and without human people as words, the world would keep repeating the laws monotonously, or limiting itself to what we are shown to be able to update out of the limit of its opportunities"14. Through words, man expresses the reasons behind things and through this rendering he

12 D. POPESCU, Iisus Hristos Pantocrator, Bucureşti, Institutul Biblic şi de Misiune al Bisericii Ortodoxe Române, 2005, p. 140.

13 "D'une manière particulière le Logos est présent dans l'homme comme sujet raisonnable. Tandis que les choses sont les images créées des raisons du Logos, le sujet humain est l'image du Logos" (see D. STANILOAE, "La centralité du Christ dans la théologie, dans la spiritualité et dans la mission orthodoxe", in Contacts. Revue orthodoxe de spiritualité et de théologie, no. 92/1975, p. 448).

${ }^{14}$ IDEM, "Cuvântul creator şi mântuitor...", p. 8. 
notices the harmony of things in the world and moves farther to being embraced in the Divine Logos, the One that has created him as speaking existence. Having been created as a speaking existence, man is a social, community-bound being that needs communication, thus being united, from the very beginning to his Creator, even though he is not always aware of that ${ }^{15}$.

The Word or the Logos has always existed, before everything we know to have had a beginning. He exists as a Person among other Persons, since the word cannot be thought about without a person, and a person without the word, and in the same manner there cannot be a word without the existence of you as a person whom he can address. Therefore, the word is personal and as a consequence it can be expressed through a person, but only in relation with another person ${ }^{16}$. Father Stăniloae shows the connection among rationality-wordcommunion in this way:

"By means of this rationality I can perceive the other. Through his word, through his presence, the other lies in me. But he is not the only one existing in me. The one I address with you, whom I therefore carry within me is himself connected with another one, with the others. As a consequence, I can make a communion with a being that is himself/herself in communion with a person. Inside you there is also the other; you are present within him, and through him, you are within me. When I speak to you, I also think about the other you are in connection with. And he works in me: he is present in me, in the responsibility I have towards him"17.

God's word has spoken from eternity to another Person like Him;

15 IDEM, Iisus Hristos lumina lumii şi îndumnezeitorul omului, Bucureşti, Anastasia, 1993, p. 34.

16 "The word is the main and indispensable means of any communication among people. The Word implies two persons. He is the dialogue, even if the other person might be silent, because through silence involves, supports the other's word " (D. STĂNILOAE, "Temeiurile eterne ale mântuirii", in Gândirea, no. 8/1941, p. 402); "The Word is a living person's relationship towards me" (D. STĂNILOAE, "Cuvântul şi mistica iubirii”, in Gândirea, no. 4/1938, p. 195).

17 Marc-Antoine Costa De Beauregard/ Dumitru Stăniloae, Mică dogmatică vorbită. Dialoguri la Cernica, rom. transl. by Maria-Cornelia Ică jr., Sibiu, Deisis, $2007^{3}$, p. 73. 
and this type of speaking that expresses one Person's love to the Other One implies the existence of a third person, due to the fact the speaking in two is a monotonous dialogue which gets exhausted without fully exploiting the dimension of the dialogue which is available through the existence of another Person. Following the Creator's model, human beings speak too, without beginning or ending, because they are the image of the Word. And their word reveals for them one for the other and for God, and their revealing actually represents the love among them and for God. To Father Stăniloae, love and rationality are interrelated.

As such, "since in the human word one experiences the communion among three people, out of whom two are talking to each other and the third one is present in their mutual thought, the Trinity of divine Persons is imitated. Divine Trinity binds and keeps every man in a threefold connection. But only by saying good things, if we speak with love about the third one, we can truly experience the responsibility towards the Holy Trinity. In this case only man can reveal himself as an accomplished individual, bearing within him the Trinity itself, that is accomplished"18.

The world, being created by the Word through the word, and man being the image of the Word, we can deduce that the world is a means, a medium for dialogue between man and the Word: "The Logos residing in man is in search of the logos residing in nature, as a reflex of the eternal Logos"19. On the other hand, via creation, divine Word did not lay the reason of things in the world through an interior law, but in connection with Him:

"The world was created through God the Word, marked by a rationality according to man's rationality, out of love for the humankind, for them to develop through its noticing his love awareness. He places in the world their reasons according to the image of His reasons at the same level with man's reason as His image, as supreme reason, in order form him to see with their help His reasons as they are within Him and

${ }^{18}$ D. STǍnILOAE, "Atragerea ierarhică a lumii spre Sfânta Treime prin Cuvântul lui Dumnezeu făcut om”, in Mitropolia Olteniei, no. 2/1991, p. 26-27.

${ }^{19}$ D. STĂNILOAE, "Simbolul ca anticipare şi temei al posibilităţii icoanei", in Studii Teologice, no. 7-8/1957, p. 435. 
through reason, to unite with Him just like supreme Reason. The reasons placed in things and in man serve the action of man's growth in his love for God the word, in the service of seeing His love which is revealed through them" 20 .

The rationality of the world is directed exclusively to man's rationality as the only being able to use this rationality for his own use, spiritual growth and accomplishment. And the rationality of this world, which is united and unitary in the Divine Logos, addressing itself to human rationality, shows that the world is the work of a wise intelligence, which is almighty at the same time. But the world, as the work of the Pantocrator Logos, does not have a static or opaque rationality, due to the fact that its rationality, having its source, foundation and grounds in the Divine Logos, is oriented towards Him from the very beginning. Therefore, even though contingent in itself, the world has a flexible structure in the sense of multiple virtuality. Father Stăniloae shows that:

"The rationality of the world discovers its meaning by means of the fact that it adds up to the rationality of the human subject, which is conscious and having an unlimited richness, which is not a monotonous repetition. It is a rationality that discovers, chooses and aims at higher and higher goals, towards which it advances by using nature itself, not in a monotonous repetition, but with a continuously new understanding of things and by the free choice of several other ways, out of the most known of them, through new ways of applying the natural laws, aiming at results that are getting more and more useful" 21 .

For Father Stăniloae the world and the things in it are directed to human rationality by means of the fact that $\mathrm{He}$ has considered them in advance, as everlasting reasons, and then He created them, providing them with content and exterior cover adapted to human reason, so as through their thinking and speaking man should grow in his relationship with his peers, and through this they should reach a dialogue with Him, as all-creator and all-supporter. The man begins to discover the meanings of things by their initial use towards their material, biologic use, so as to be able to look and discover new meanings that exceed this genuinely material meaning. But, in this case, man should not be dominated by

${ }^{20}$ IDEM, “Atragerea ierarhică a lumii...”, p. 29-30.

${ }^{21}$ IDEM, Teologia Dogmatică Ortodoxă, vol. 1, p. 238. 
material things; he should be able to find in them the perpetual means of enhancing interpersonal communion, personal transparency.

"Things discover their meaning, as their rationality is perceived by man having its unitary source in personal God, since they are seen as means of God's love, therefore of God's dialogue with us and of the dialogue among us, a dialogue through which God leads us to a deeper knowledge of His thinking and love and to a boost in our own thinking and love in the relationship between us and God. The dialogue with God via things contributes to our growth, due to the fact that all these are seen as images and symbols or as transparent facets of God's reasons, of the meanings aimed at through their creation, meanings through which He wants to take us closer to Him and to our own personal growth, on condition that we discover and undertake them",22.

The Rationality of the world is directed towards man, as a free being; therefore, man's progress and development is the product of personal will and effort. Man does not have a passive character, as compared to the world in its relationship with man, but an active character in his existence. His freedom meets God's freedom,states Father Stăniloae, but this meeting does not mean clash, but cooperation, when man directs himself according to exterior nature and his own nature. Man's responsibility, both to nature, as well as to himself and his peers arise also from his freedom. The everlasting love that exists among the persons of the Holy Trinity implies and assumes absolute freedom, because love can abide only among free people, otherwise being merely a determination and unity by mistake. And God offers this freedom in the sense of self-determination to His most special being, man. Through this freedom, man can even rise against His creator, against His love but, however, He cannot entirely abolish all the connections between him and the world, between him and His Creator.

\section{References}

1. Costa De Beauregard, Marc-Antoine / StăniloAe, Dumitru, Mică dogmatică vorbită. Dialoguri la Cernica, rom. transl. by Maria-Cornelia Ică jr., Sibiu, Deisis, $2007^{3}$.

${ }^{22}$ Ibidem, p. 245. 
2. IORDACHE, Siţa, "Persoană şi comuniune în teologia Sfântului Vasile cel Mare" in Theologia Pontica, Revista Centrului de cercetări teologice, interculturale şi ecumenice "Sfântul Ioan Cassian", no. 2-4/2009.

3. POPESCU, Dumitru, Iisus Hristos Pantocrator, București, Institutul Biblic şi de Misiune al Bisericii Ortodoxe Române, 2005.

4. POPESCU, Dumitru, Teologie şi viaţă. Relevanţa teologiei ortodoxe in lumea contemporană, Convorbiri cu conf. univ. dr. Cristinel Ioja, Alexandria, Cartea Ortodoxă, 2009.

5. St. DiONISIE AREOPAGITUL, Opere complete şi scoliile Sfântului Maxim Mărturisitorul, rom. transl., introduction and notes by D. Stăniloae, București, Paideia, 1996.

6. SAINT MAXIMUS THE CONFESSOR, Ambigua, rom. transl., introduction ad notes by D. Stăniloae, București, Institutul Biblic şi de Misiune al Bisericii Ortodoxe Române, 2006.

7. STĂniloAe, Dumitru, "Cuvântul şi mistica iubirii", in Gândirea, no. 4/1938.

8. STĂNILOAE, Dumitru, "Dinamica creaţiei în Biserică", in Ortodoxia, no. 3-4/1977.

9. StĂNiloAe, Dumitru, "Simbolul ca anticipare şi temei al posibilităţii icoanei”, in Studii Teologice, no. 7-8/1957.

10. STĂNILOAE, Dumitru, "Temeiurile eterne ale mântuirii", in Gândirea, no. 8/1941.

11. StĂNiloAe, Dumitru, "Atragerea ierarhică a lumii spre Sfânta Treime prin Cuvântul lui Dumnezeu făcut om", in Mitropolia Olteniei, no. 2/1991.

12. STĂNILOAE, Dumitru, "Cuvântul creator şi mântuitor şi veşnic înnoitor", in Mitropolia Olteniei, no. 1/1991.

13. StaniloAe, Dumitru, "La centralité du Christ dans la théologie, dans la spiritualité et dans la mission orthodoxe", in Contacts. Revue orthodoxe de spiritualité et de théologie, no. 92/1975.

14. StăniloAe, Dumitru, Iisus Hristos lumina lumii şi îndumnezeitorul omului, București, Anastasia, 1993.

15. StăniloAe, Dumitru, Sensul ascezei monahale, Alba Iulia, Reîntregirea, 2005.

16. StăniloAe, Dumitru, Sfânta Treime sau la început a fost iubirea, București, Institutul Biblic şi de Misiune al Bisericii 
Ortodoxe Române, 2005

17. StăniloAe, Dumitru, Teologia Dogmatică Ortodoxă, vol. 1, București, Institutul Biblic şi de Misiune al Bisericii Ortodoxe Române, $1996^{2}$.

18. VINTILĂ, Ovidiu, “Ontologia persoanei şi dinamismul sfinţeniei în viaţa Bisericii, în teologia Părintelui Dumitru Stăniloae”, in Altarul Reîntregirii, no. 1/2007. 